\title{
The ice nucleation ability of one of the most abundant types of fungal spores found in the atmosphere
}

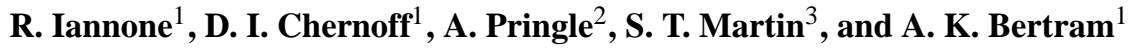 \\ ${ }^{1}$ Department of Chemistry, University of British Columbia, Vancouver, British Columbia, V6T 1Z1, Canada \\ ${ }^{2}$ Department of Organismic and Evolutionary Biology, Harvard University, Cambridge, Massachusetts, USA \\ ${ }^{3}$ School of Engineering and Applied Sciences \& Department of Earth and Planetary Sciences, Harvard University, \\ Cambridge, Massachusetts, USA
}

Received: 11 September 2010 - Published in Atmos. Chem. Phys. Discuss.: 21 October 2010

Revised: 1 February 2011 - Accepted: 1 February 2011 - Published: 11 February 2011

\begin{abstract}
Recent atmospheric measurements show that biological particles are a potentially important class of ice nuclei. Types of biological particles that may be good ice nuclei include bacteria, pollen and fungal spores. We studied the ice nucleation properties of water droplets containing fungal spores from the genus Cladosporium, one of the most abundant types of spores found in the atmosphere. For water droplets containing a Cladosporium spore surface area of $\sim 217 \mu \mathrm{m}^{2}$ (equivalent to $\sim 5$ spores with average diameters of $3.2 \mu \mathrm{m}), 1 \%$ of the droplets froze by $-28.5^{\circ} \mathrm{C}$ and $10 \%$ froze by $-30.1{ }^{\circ} \mathrm{C}$. However, there was a strong dependence on freezing temperature with the spore surface area of Cladosporium within a given droplet. Mean freezing temperatures for droplets containing 1-5 spores are expected to be approximately $-35.1 \pm 2.3^{\circ} \mathrm{C}(1 \sigma \mathrm{S}$. D. $)$. Atmospheric ice nucleation on spores of Cladosporium sp., or other spores with similar surface properties, thus do not appear to explain recent atmospheric measurements showing that biological particles participate as atmospheric ice nuclei. The poor ice nucleation ability of Cladosporium sp. may be attributed to the surface which is coated with hydrophobins (a class of hydrophobic proteins that appear to be widespread in filamentous fungi). Given the ubiquity of hydrophobins on spore surfaces, the current study may be applicable to many fungal species of atmospheric importance.
\end{abstract}

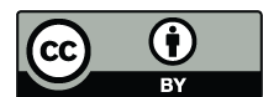

Correspondence to: A. K. Bertram (bertram@chem.ubc.ca)

\section{Introduction}

Ice nucleation can occur in the atmosphere by either homogeneous nucleation or heterogeneous nucleation. Heterogeneous nucleation involves solid or partially solid particles, called ice nuclei (IN), that have the potential to modify climate by changing the formation conditions and properties of ice clouds and mixed-phase clouds (Baker and Peter, 2008; Hegg and Baker, 2009; Lohmann and Hoose, 2009). At temperatures greater than approximately $-38^{\circ} \mathrm{C}$, freezing occurs initially by heterogeneous nucleation on ice nuclei. Possible atmospheric ice nuclei include mineral dust (DeMott et al., 2003; Hung et al., 2003; Pruppacher and Klett, 1997), soot (Andreae and Rosenfeld, 2008; Kärcher et al., 2007), crystalline salts (Abbatt et al., 2006; Martin, 1998; Shilling et al., 2006; Wise et al., 2010; Zuberi et al., 2002), and biological aerosol particles (Christner et al., 2008; Möhler et al., 2007).

Several recent reviews have highlighted the need to quantify the number and source of biological ice nuclei in the atmosphere (Ariya et al., 2009; DeMott and Prenni, 2010; Martin et al., 2010; Möhler et al., 2007; Szyrmer and Zawadzki, 1997). In addition, it has been suggested that the most important carbonaceous particles that may be acting as ice nuclei above $-15^{\circ} \mathrm{C}$ may be biological particles (DeMott and Prenni, 2010). If biological ice nuclei are abundant in the atmosphere they can influence the hydrological cycle and may play an important role in precipitation (Sands et al., 1982; Morris et al., 2004).

Recent field measurements of IN have highlighted the potential importance of biological particles in ice cloud formation in the atmosphere (Pratt et al., 2009; Prenni et al., 2009). Pratt et al. (2009) observed that ice residuals collected in situ from cloud particles (from $-31{ }^{\circ} \mathrm{C}$ to $-34^{\circ} \mathrm{C}$ )

Published by Copernicus Publications on behalf of the European Geosciences Union. 
contain a significant fraction of biological material. Another recent study concerning biological IN has demonstrated that, for pristine conditions over the Amazon rainforest, the level of IN can be predicted though measurements of a combination of mineral dust and biological particles (Prenni et al., 2009). To account for their data they had assumed that the sampled biological particles could induce ice nucleation with an efficiency of $\sim 0.2$ for temperatures between $-18^{\circ} \mathrm{C}$ and $-31^{\circ} \mathrm{C}$. At temperatures above approximately $-25^{\circ} \mathrm{C}$ biological IN appeared to dominate over mineral dust IN.

Types of biological particles that can act as IN include bacteria, pollen and fungal spores. The most well-characterized biological IN species is the bacterium Pseudomonas syringae (P. syringae). This bacterium is an efficient IN species that is associated with onsets for ice formation as high as $-2{ }^{\circ} \mathrm{C}$ (Möhler et al., 2007; Lindow et al., 1989; Maki et al., 1974; Morris et al., 2004; Vali et al., 1976). The ice nucleating ability of pollen, relatively large bioaerosol particles with a diameter range of $10-100 \mu \mathrm{m}$, has been addressed in several studies (Diehl et al., 2001, 2002; von Blohn et al., 2005). Freezing temperatures for 4 types of pollen particles in the immersion freezing mode ranged from $-13.5^{\circ} \mathrm{C}$ to $-21.5^{\circ} \mathrm{C}$ (von Blohn et al., 2005). However, the fraction of pollen grains that are effective IN have not yet been determined.

Concerning the IN ability of fungi, a study by Pouleur et al. (1992) had examined the IN capability of suspensions of 20 fungal species at temperatures as low as $-10.0^{\circ} \mathrm{C}$. However, the IN ability of fungal spores was not specifically determined.

Recent modelling studies have begun to explore the effect of biological ice nucleation on cloud microphysics, dynamics and precipitation (Diehl et al., 2006; Hoose et al., 2010; Phillips et al., 2009). However, due to the limited understanding of the ice nucleation properties of biological particles, such modelling studies often have significant uncertainties. More studies on the ice nucleation properties of biological particles are needed, especially focusing on the abundant types of biological particles found in the atmosphere.

Spores, which are the reproductive units of fungi, are liberated into the air and are dispersed by air currents into the atmosphere. The amount of fungal spores in the atmosphere is subject to the time of day and meteorological factors (Gilbert and Reynolds, 2005; Hirst, 1953; Kurkela, 1997; Stennett and Beggs, 2004; Stȩpalska and Wołek, 2009). The average number of fungal spores in the continental boundary layer air is on the order of $10^{3}-10^{4} \mathrm{~m}^{-3}$ (Elbert et al., 2007). As a result, they are of sufficient quantity for their consideration in ice cloud formation. To determine their atmospheric relevance, knowledge of their activation spectrum (i.e., proportion of active IN against temperature and ice supersaturation) is needed. Fungal spores can also be transported over vast distances. By convection, they can reach high altitudes in the troposphere (Fulton, 1966; Fulton and Mitchell, 1966; Gregory, 1978; Heise and Heise, 1948; Hirst et al., 1967a, b; Pady and Kelly, 1953; Proctor, 1935;
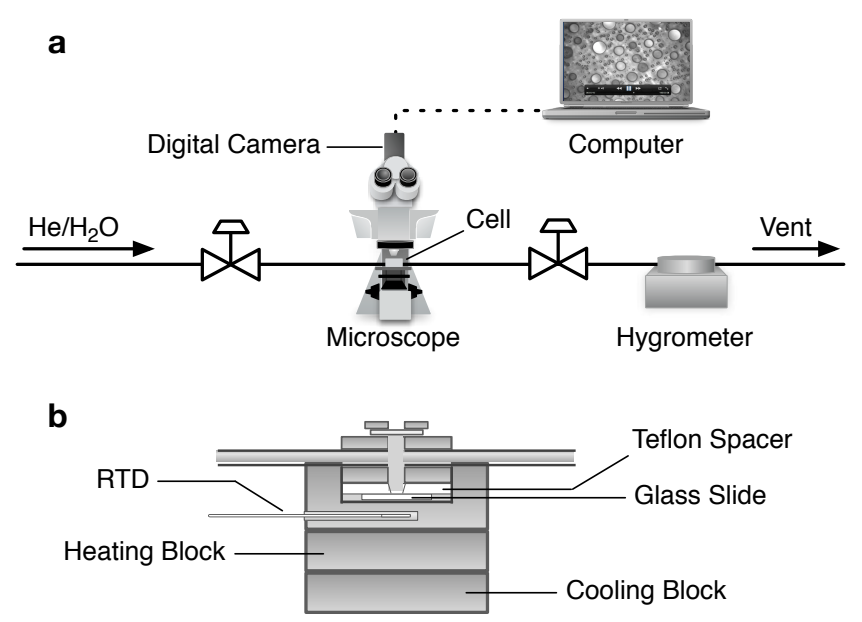

Fig. 1. Schematics of the optical microscopy technique coupled with a temperature-controlled cell and a CCD camera. Panel (a) indicates the basic arrangement of the instrumental components with relation to the gas flow of humidified He. Panel (b) provides a detailed view of the components that comprise the flow cell.

Proctor and Parker, 1938), and even up to the mesosphere (Imshenetsky et al., 1978).

This investigation focuses on the ice nucleation properties of one of the most abundant types of fungal spores found in the atmosphere: spores from the genus Cladosporium. Species of Cladosporium are regularly found on living and dead plant material. The spores of Cladosporium are passively launched (i.e, separated from the mycelium via wind currents) and they have mean aerodynamic diameters between roughly 2-4 $\mu \mathrm{m}$ (Fröhlich-Nowoisky et al., 2009; Hameed and Khodr, 2001; Jung et al., 2009b; Reponen et al., 2001). Spores of Cladosporium have been frequently observed as the dominant spore near the ground in sampling studies, where they often comprise at least $35 \%$ of the total count as a yearly average (Al-Subai, 2002; Herrero et al., 2006; Li and Kendrick, 1995; Lim et al., 1998; Mallo et al., 2011; Mitakakis and Guest, 2001; Pyrri and KapsanakiGotsi, 2007).

In these studies an optical microscope coupled with a temperature-controlled flow cell and a CCD camera were used to observe ice nucleation events for spores immersed in droplets of ultrapure water. These measurements were then used to assess the importance of ice nucleation on Cladosporium spores in the atmosphere.

\section{Experimental}

Experiments were carried out with a slightly modified apparatus to that used for ice nucleation experiments of organic materials (Parsons et al., 2004), mineral dust (Eastwood et al., 2008), and soot (Dymarska et al., 2006). The current method allows for observations of the freezing of 
spore-containing water droplets. Additionally, the amount of fungal material present in the droplets was directly determined through the analysis of acquired video after evaporating the drops, providing insight on the relationship between the spore surface area and the heterogeneous freezing temperature.

\subsection{Freezing experiments and apparatus}

The apparatus used in the freezing measurements consisted of an optical microscope (Zeiss Axiolab A) coupled to a flow cell wherein the relative humidity $(\mathrm{RH})$ could be accurately controlled and the temperature could be decreased or increased at a fixed rate ranging from $0.1-5.0^{\circ} \mathrm{C} \mathrm{min}^{-1}$. Only one cooling rate, $5 \mathrm{~K} \mathrm{~min}^{-1}$, was used due to experimental constraints. Higher cooling rates were not possible with the current setup and lower cooling rates resulted in significant mass transfer between unfrozen and frozen droplets. A schematic of the flow cell is shown in Fig. 1. The optical microscope was equipped with a $10 \times$ objective and a Sony XC-ST50 digital video camera, itself fitted with a $0.4 \times$ reduction lens. The temperature of the flow cell was controlled using a combination of a refrigerating circulator (ULT-95, Thermo Neslab) and an electrical heater supported by a temperature controller. Cell temperature was monitored through the use of a Pt-100 resistance temperature detector (RTD).

The bottom surface of the flow cell, which supported the spores during the freezing experiments, consisted of a presiliconized glass cover slide (Hampton Scientific, Hartfield, PA) that served as a hydrophobic substrate for reducing the probability of ice nucleation directly on the surface. It was previously demonstrated that these types of slides do not induce heterogeneous freezing of supercooled water droplets (Koop et al., 1998).

The experimental protocol for the freezing experiments consisted of the following steps. Cladosporium spores were deposited on the bottom surface of the flow cell using the procedure described in Sect. 2.3. Next, the temperature of the flow cell was decreased to $2{ }^{\circ} \mathrm{C}$ and the dew point in the flow cell was set to approximately $3-5^{\circ} \mathrm{C}$ using a humidified flow of ultra high purity (UHP) He (99.999\%, Praxair). This resulted in the nucleation and growth of water droplets on the bottom surface of the flow cell and on the spores. Droplets were allowed to grow to $200-300 \mu \mathrm{m}$ in diameter. The gas flow was then stopped and the flow cell was isolated by closing the valves immediately upstream and downstream of the cell. Next, the temperature in the flow cell was decreased at a rate of $5^{\circ} \mathrm{C} \min ^{-1}$ until a temperature of $-40^{\circ} \mathrm{C}$ was reached. During this process, digital video was captured at a frame rate of $30 \mathrm{fps}$ (frames per second) by use of the CCD camera. Images were acquired from the digital video and analysed to determine the freezing spectrum, defined as the fraction of droplets frozen as a function of temperature. After freezing, the temperature was increased to $2{ }^{\circ} \mathrm{C}$ and the droplets were exposed to a flow of dry He gas to fully evapo- rate the water, leaving only the spore inclusions on the slide. Images were also acquired during this procedure to determine the amount of fungal material contained in each droplet.

Figure 2 provides images of a droplet in a heterogeneous nucleation experiment at various conditions during an experiment. Panel a shows a droplet containing inclusions at the beginning of the freezing experiment. Panels $\mathrm{b}$ and $\mathrm{c}$ show images of the same droplets after freezing. Panel d shows an image of the remaining fungal spore inclusions after evaporating the droplet.

Experiments were also performed using ultrapure water droplets without spores. This provided a means to determine whether the hydrophobic substrate supporting the particles influenced the freezing results. In these experiments, pure water droplets were condensed from the vapour phase onto the hydrophobic surface and their freezing temperatures were determined using the same procedure as outlined above for heterogeneous freezing.

\subsection{Temperature and cooling rate calibration}

The RTD was calibrated against the melting points of ultrapure water $\left(0.0^{\circ} \mathrm{C}\right)$ and $\mathrm{n}$-decane $\left(-29.7^{\circ} \mathrm{C}\right)$. Melting point determinations indicated a $+0.16^{\circ} \mathrm{C}$ offset for $\mathrm{n}$-decane and $\mathrm{a}+0.07^{\circ} \mathrm{C}$ offset for water. The reported freezing temperatures were corrected for bias using a fit function based on this offset data.

\subsection{Preparation and collection of spores of Cladosporium sp.}

Cladosporium was obtained from existing stock at the Canadian Centre for the Culture of Microorganisms (CCCM) (Department of Botany, University of British Columbia, Canada). Colonies of Cladosporium were grown on potato dextrose agar in plastic Petri dishes. The cultures were incubated for a minimum of 3 weeks at $26^{\circ} \mathrm{C}$ before any experiments were carried out. Preparation and collection of spores were conducted in a Class II biological safety cabinet to avoid contamination of the samples by dust and to prevent the release of spores into the laboratory environment.

Spores were harvested from fungal colonies and deposited on hydrophobic slides using a spore dispenser (i.e., an RH meter and a flow cell) and an impactor (Fig. 3). A scalpel was used to excise portions of the Cladosporium cultures from the Petri dish which were then transferred to a sterilized borosilicate glass flow tube. The tube was placed inside the flow cell and the spore dispenser was then hermetically sealed.

Inside the flow cell, UHP $\mathrm{N}_{2}$ gas (99.999\%, Praxair) was passed over the fungal cultures to dislodge and aerosolize the spores. A flow rate of $5 \times 10^{3} \mathrm{~cm}^{3} \mathrm{~min}^{-1}$ was maintained during a $1 \mathrm{~h}$ collection time. A $120 \mathrm{~cm}^{3}$ Supelcarb HC Hydrocarbon Trap (Sigma-Aldrich) minimized organic contaminants within the $300 \mathrm{~L}$ of $\mathrm{N}_{2}$ admitted to the system during 

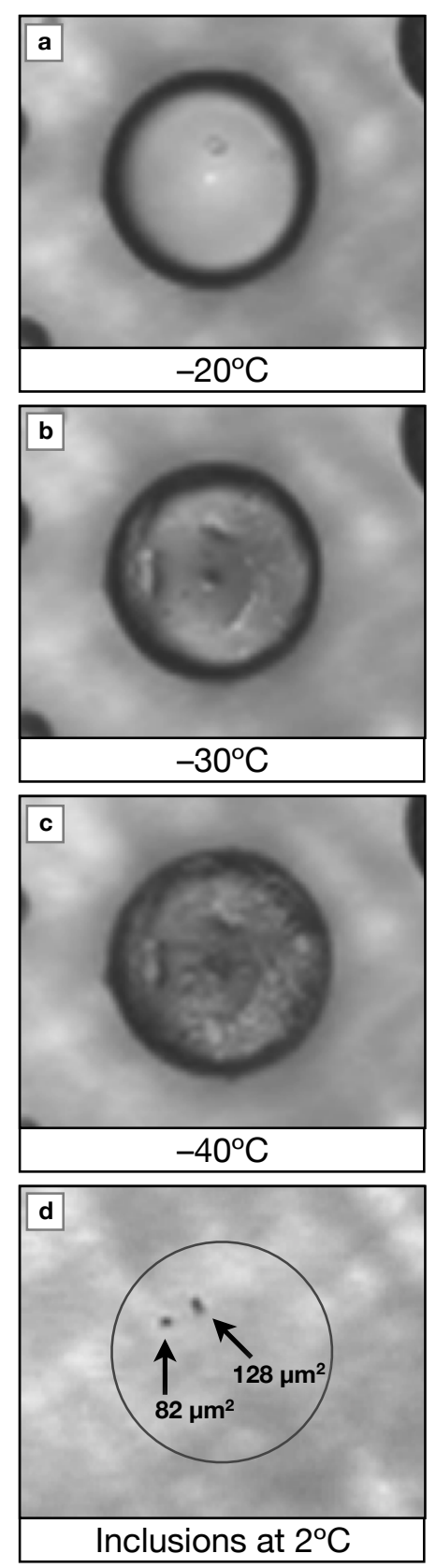

$100 \mu \mathrm{m}$

Fig. 2. Images from a heterogeneous nucleation experiment. Image (a) shows a liquid water droplet (cell temperature of $-20.0^{\circ} \mathrm{C}$ ) containing Cladosporium spore inclusions (not visible) where no freezing has yet occurred. Images (b and $\mathbf{c}$ ) (cell temperatures of $-30.0^{\circ} \mathrm{C}$ and $-40.0^{\circ} \mathrm{C}$, respectively) show the droplet after freezing. Image (d) depicts the remaining inclusions (with a total area of $210 \mu \mathrm{m}^{2}$ ) upon evaporating the droplets at $2.0^{\circ} \mathrm{C}$ and passing dry He gas through the cell. For reference, the droplet boundary is provided as a black outline and the individual areas of the inclusions are given. spore collection. Experiments used either dry $\mathrm{N}_{2}$ or a humidified flow of $\mathrm{N}_{2}$ ( $\left.\mathrm{RH} \sim 35 \%\right)$. Impaction of the spores onto the hydrophobic glass substrate occurred as the $\mathrm{N}_{2}$ carrier gas exited a borosilicate glass impactor tube.

An Olympus IX70 inverted microscope equipped with a $40 \times$ objective was used to determine the morphology of the particles. A $20 \times$ objective was used to determine the size distributions of the collected spores.

\section{Results and discussion}

\subsection{Morphology and size distribution of collected spores}

Individual spores often appeared to be either roughly circular or, alternatively, lemon-shaped. Figure 4 provides several images of Cladosporium sp. spores at $40 \times$ magnification using the Olympus IX70 microscope. The morphology of these spores and their aspect ratios are consistent with results reported in the literature (Reponen et al., 1997; Schubert et al., 2007). Approximately $90 \%$ of the spore dispersal units (i.e., particles dislodged from the fungal mycelium) contained 1 spore (Fig. $4 \mathrm{a}-\mathrm{c}$ ), and the remaining $10 \%$ contained 2 or more spores (Fig. 4d, e). Observations in the atmosphere at ground level have shown that a significant fraction of the collected spore dispersal units contain 2 or more spores (Davies, 1957; Harvey, 1967; Hyde and Williams, 1953).

In addition to characterising the morphology of the spores, we also determined the size distribution of individual spores to further confirm that the collected material was actually spores and also to provide an estimate of the size of spores used in our studies. Volume equivalent diameters ( $D_{\text {volume }}$ ) for each individual spore were calculated using images recorded at $20 \times$ magnification with the IX70 microscope and the formula $D_{\text {volume }}=\sqrt[3]{W^{2} \cdot L}$, where $W$ represents the maximum width orthogonal to the length $L$ (Reponen et al., 2001). Any dispersal unit that contained 2 or more spores (i.e., Fig. 4d, e) was not included in these calculations. The results from these calculations are shown in Fig. 5. Individual spores had a mean volume equivalent diameter of $3.2 \pm 1.0 \mu \mathrm{m}(1 \sigma \mathrm{S}$. D.). This mean diameter is consistent with reported diameters for spores of Cladosporium (Carlile et al., 2001; Fröhlich-Nowoisky et al., 2009; Hameed and Khodr, 2001; Jung et al., 2009a; Reponen et al., 1997). The mean diameter may be an upper limit to the true mean size, because in our experiments particles having diameters less than approximately $1 \mu \mathrm{m}$ were not resolved with the microscope. The mean size corresponds to single spores collected with the impactor. In the freezing experiments an average of 4.8 spores (i.e., spore units) was contained in each droplet (cf. Sect. 3.3). 

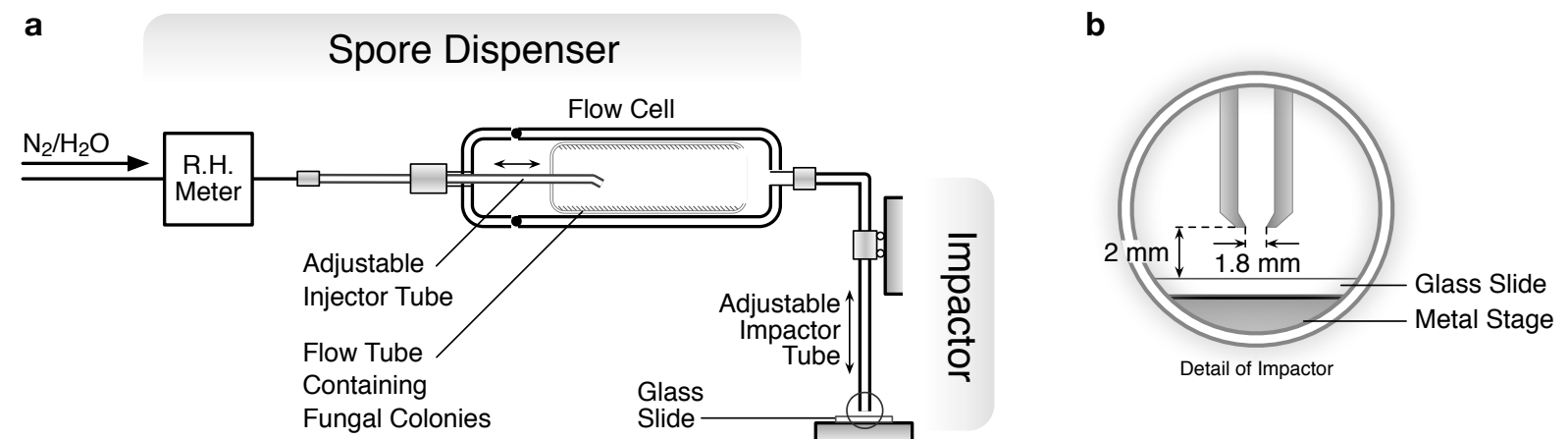

Fig. 3. Schematics for the collection of fungal spores using a spore dispenser and an impactor. Panel (a) depicts the arrangement of the of the spore dispenser and impactor. Panel (b) provides a detailed view of the impactor, where the impactor tube's aperture size and the distance from glass slide are given. Excised portions of Cladosporium cultures were placed inside the borosilicate glass flow tube. The tube was sealed inside the flow cell where a $1 / 4 \mathrm{O}$. D. stainless steel tube with bent tip directed a flow of $\mathrm{N}_{2}\left(\sim 5 \times 10^{3} \mathrm{~cm}^{3} \mathrm{~min}^{-1}\right.$ for $\left.1 \mathrm{~h}\right)$ at the cultures. Experiments either used dry or humidified ( $\sim 35 \%$ relative humidity, or $\mathrm{RH}) \mathrm{N}_{2}$ gas.

\subsection{Pure water droplets}

A total of 113 individual homogeneous freezing events was observed for pure water droplets without spores. Figure 6 provides a summary of the freezing results. As shown, 50\% of the droplets had frozen at approximately $-37^{\circ} \mathrm{C}$, which is within the range of temperatures expected when considering classical homogeneous nucleation theory. In Fig. 7, the mean homogeneous freezing data is plotted as a function of droplet size (binned in $20 \mu \mathrm{m}$ diameter bins). From the plotted data, a small dependence of freezing temperature on droplet size was observed as expected from classical nucleation theory (Pruppacher and Klett, 1997). The mean freezing temperatures for all the size ranges studied are within $0.5-2.0^{\circ} \mathrm{C}$ of the predicted homogeneous freezing temperatures using homogeneous nucleation rates and equations presented in Pruppacher (1995) and Pruppacher and Klett (1997). In addition, the measured freezing temperatures are in good agreement with freezing temperatures reported in other studies for which unsupported droplets (i.e., aerosol droplets) were used. Wood et al. (2002), for example, reported average freezing temperatures of $-37.0^{\circ} \mathrm{C}$ to $-37.3^{\circ} \mathrm{C}$ for droplet diameters of 40-66 $\mu \mathrm{m}$. The reasonable agreement between the predicted homogeneous freezing temperatures, previous homogeneous freezing experiments, and the results of this study illustrates that the hydrophobic surface supporting the particles does not significantly influence the freezing temperatures. This observation is consistent with previous measurements using similar supports (Bertram et al., 2000; Koop et al., 1998).

\subsection{Heterogeneous nucleation}

Nine freezing experiments were carried out for water droplets containing fungal spores of Cladosporium, and 1643 droplets were analysed for freezing in each experiment.
Only droplets that presented clear visual evidence for freezing and that contained spores were considered for the heterogeneous nucleation analyses. A total of 292 individual heterogeneous freezing events was observed. In these experiments the average surface area for the spore inclusions was $217 \mu \mathrm{m}^{2}\left(\sigma=172 \mu \mathrm{m}^{2}\right)$. Assuming that one spore corresponds to a diameter of $3.2 \mu \mathrm{m}$ (as presented in Sect. 3.1) then, on average, each droplet in these experiments contained 4.8 spores.

The results from the heterogeneous freezing experiments are summarized in Fig. 6. As seen, the heterogeneous freezing results are warmer than the pure water freezing experiments, where $1 \%$ of the droplets heterogeneously froze at $-28.5^{\circ} \mathrm{C}$ and $10 \%$ froze at $-30.1^{\circ} \mathrm{C}$. It is interesting to note that the ice nucleation ability of Cladosporium is similar to kaolinite in the immersion mode (Murray et al., 2010; Lüönd et al., 2010). Kaolinite, an abundant mineral in the atmosphere, is often considered a good ice nucleus.

In Fig. 7, the heterogeneous freezing results are plotted as a function of droplet diameter in the same manner as for the freezing experiments of pure water droplets. This plot illustrates that the heterogeneous freezing results are statistically different from the pure water case and, hence, the fungal spores are acting as ice nuclei. The difference between homogeneous and heterogeneous freezing ranges from $\sim 3{ }^{\circ} \mathrm{C}$ to $\sim 5^{\circ} \mathrm{C}$.

Another way to analyse and present the heterogeneous freezing data is to do so as a function of inclusion size (i.e., surface area) contained within each droplet undergoing heterogeneous nucleation. A summary of the heterogeneous data binned according to inclusion area is provided in Fig. 8. Included for comparison are the homogeneous data (zero surface area). Included as a secondary $\mathrm{x}$-axis is the number of spores in each droplet, assuming an average spore diameter of $3.2 \mu \mathrm{m}$ for the size of an individual spore. The general trend observed in Fig. 8 is an increase in the median 


\section{One Spore Unit}
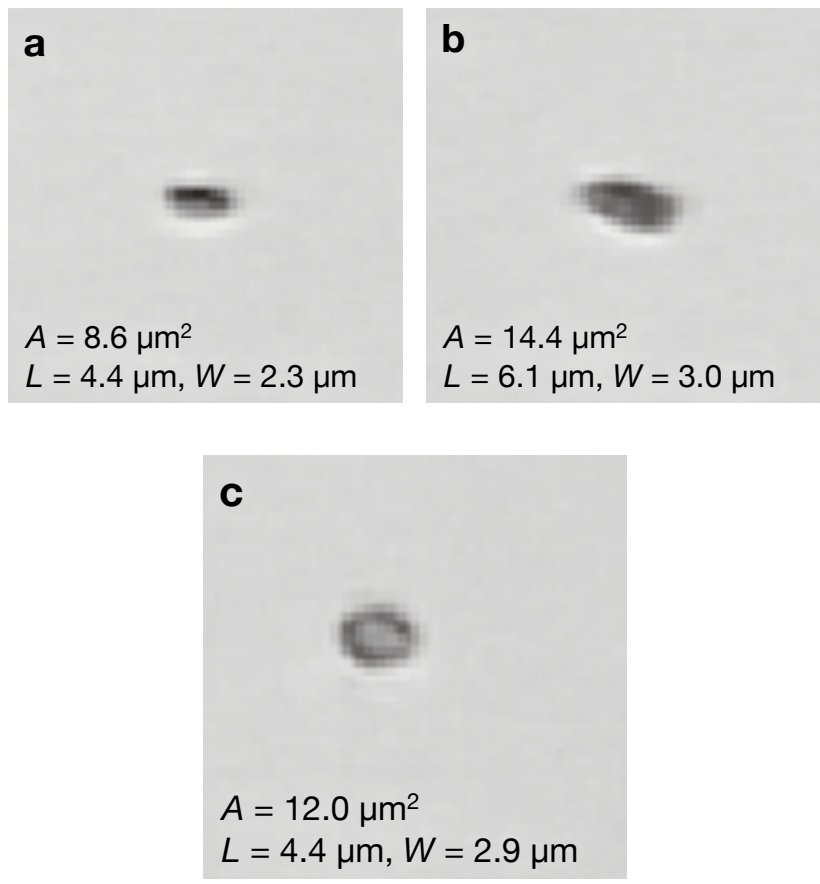

Two Spore Units

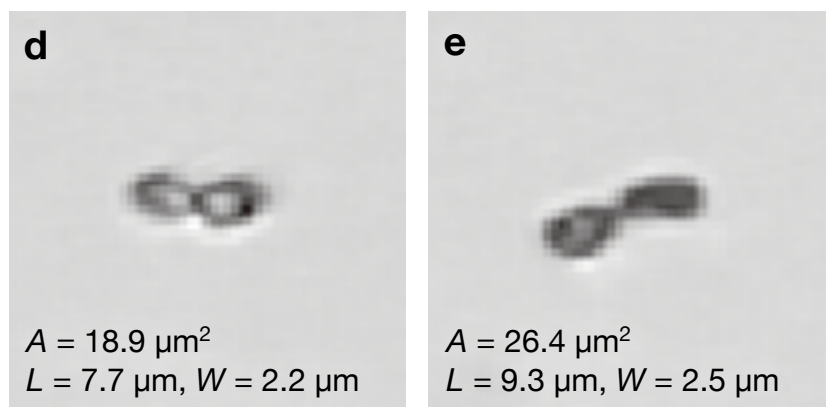

Fig. 4. Images of spores of Cladosporium collected on a glass slide and observed with the Olympus IX70 microscope at 40× magnification. Panels (a-c) show dispersal units for Cladosporium containing one spore, whereas panels ( $\mathrm{d}$ and $\mathrm{e}$ ) depict observations of two or more spores (comprising $10 \%$ of the total observations during size studies at the $20 \times$ magnification level). Each image measures $20 \mu \mathrm{m} \times 20 \mu \mathrm{m}$. Measurement values for area $(A)$, length $(L)$, and width $(W)$ are provided in each panel.

freezing temperature as the surface area of the inclusion increases per droplet (i.e., as the number of spores per droplet increases). This trend is consistent with previous heterogeneous freezing experiments in which the freezing temperature depended on the surface area of the heterogeneous ice nuclei (Archuleta et al., 2005; Hung et al., 2003; Kanji et al., 2008; Marcolli et al., 2007; Phillips et al., 2008). The median heterogeneous freezing temperature for the smallest size bin $\left(10-200 \mu \mathrm{m}^{2}\right)$ is approximately $3{ }^{\circ} \mathrm{C}$ warmer compared to the homogeneous nucleation data. The dependence of spore

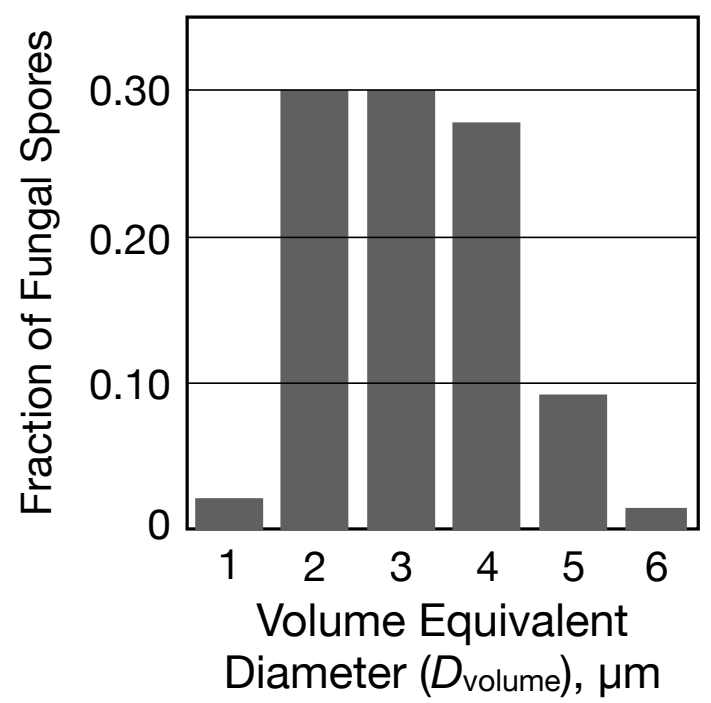

Fig. 5. Distribution of volume equivalent diameters $\left(D_{\text {volume }}\right)$ for spores of Cladosporium observed with the Olympus IX70 microscope at $20 \times$ magnification. Only spore areas for one spore unit were included in calculations of $D_{\text {volume }}$. Data are centered on integer values for $D_{\text {volume }}$. The mean volume equivalent diameter is $3.2 \pm 1.0 \mu \mathrm{m}$ ( $1 \sigma \mathrm{S}$. D.).

inclusions on freezing temperatures has a pronounced effect especially for $>8$ spores droplet ${ }^{-1}$ at which point the average difference in supercooling between homogeneous nucleation and heterogeneous nucleation is $8^{\circ} \mathrm{C}$.

There is a paucity of studies on the heterogeneous freezing of fungal spores for which comparisons may be made to this study. One study examined the IN ability of a wide variety of fungal genera, including 14 species of the genus Fusarium (Pouleur et al., 1992). That study reported high freezing temperatures for the genus Fusarium (up to $-2.5^{\circ} \mathrm{C}$ ). A caveat, however, is that the experiments were performed on droplets containing a suspension of fungal material and this does not provide specific results on the ice nucleating ability of fungal spores. Furthermore, the dependence on surface area was not addressed. Similarly, several ice nucleation experiments were carried out with species of lichens (Ashworth and Kieft, 1992; Kieft, 1988; Kieft and Ahmadjian, 1989; Kieft and Ruscetti, 1990), which are symbiotic organisms wherein fungi and algae and/or cyanobacteria form a single biological entity (Nash, 2008). In one particular study, Rhizoplaca chrysoleuca, a species of lichen, was found to induce freezing at approximately $-4{ }^{\circ} \mathrm{C}$ (Kieft and Ruscetti, 1990). However, the ice nucleation properties of spores from lichens were not addressed.

Compared to biological particles such as the bacterium P. syringae, Cladosporium is not an effective IN. For example, strains of $P$. syringae induce freezing at temperatures as high as $-2^{\circ} \mathrm{C}$ (Lindow et al., 1989; Maki et al., 1974; Morris et al., 2004a) and for some strains a freezing fraction 

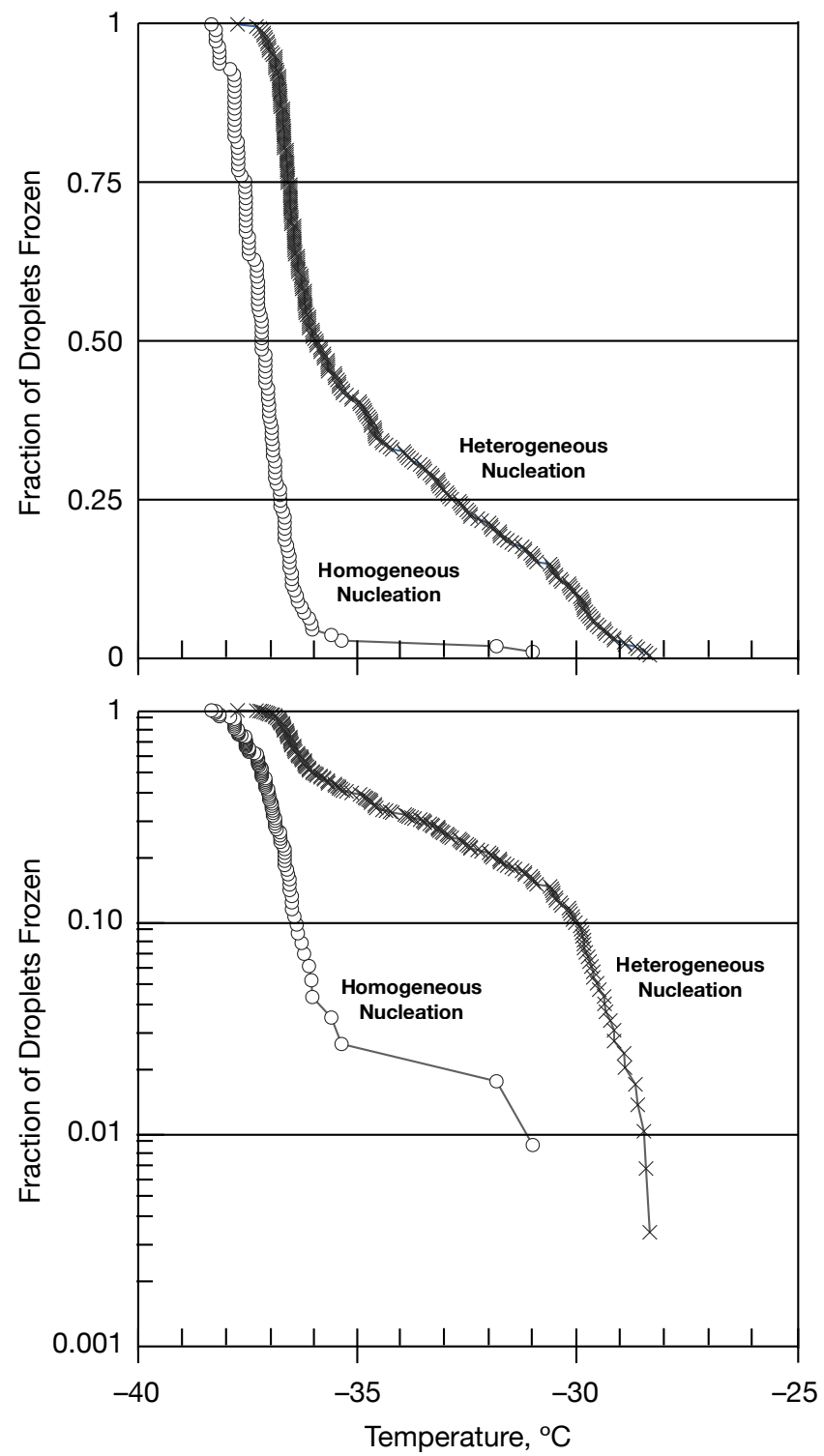

Fig. 6. Combined data for homogeneous nucleation experiments (113 freezing events) and heterogeneous nucleation experiments (292 freezing events). Both graphs show the same data but the bottom graph has been plotted on a logarithmic y-axis.

of $10^{-2}$ (i.e., the fraction of particles that are good IN) is reached at a supercooling of only $10-12{ }^{\circ} \mathrm{C}$ (cf. Fig. 1 in Phillips et al. (2009)). There is evidence that the high effectiveness of these IN species is due to a protein located in the outer cell membrane that provides a suitable crystallographic match for water clusters (Green and Warren, 1985; Gurian-Sherman and Lindow, 1993; Lee et al., 1995; Morris et al., 2004; Szyrmer and Zawadzki, 1997; Kajava and Lindow, 1993). The poor ice nucleation ability of Cladosporium spores compared to $P$. syringae is believed to be related to the composition of the spore surfaces.

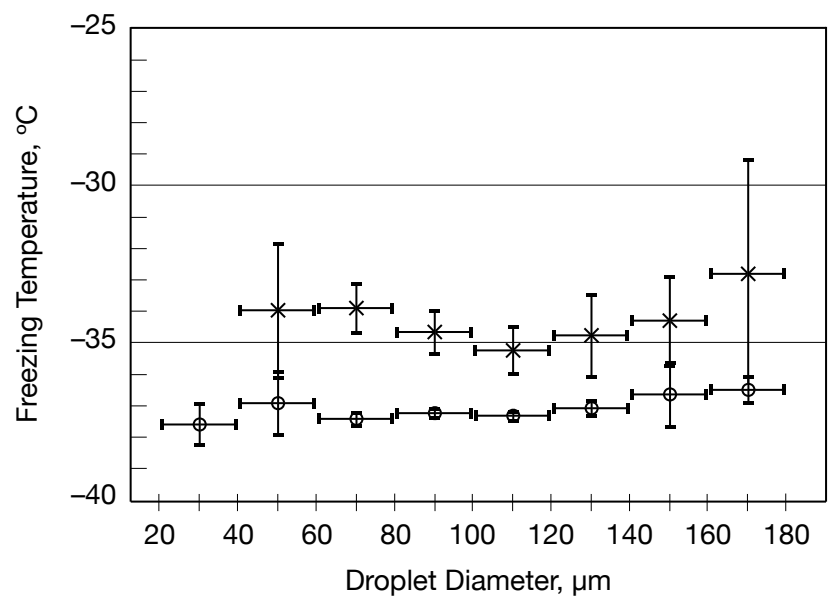

Fig. 7. Combined data for mean freezing temperatures against binned droplet diameters $(20 \mu \mathrm{m}$ wide intervals for each droplet diameter size bin) from homogeneous $(\bigcirc)$ and heterogeneous $(x)$ nucleation experiments. Horizontal lines provide ranges for each of the $20 \mu \mathrm{m}$ diameter size bins. Vertical lines represent bounds for the $95 \%$ confidence interval about each mean.

Spores from several species within the genus Cladosporium have been shown to be coated with a proteinaceous, hydrophobic rodlet layer (Aimanianda et al., 2009; Latgé et al., 1988). The rodlet layer is largely composed of proteins called hydrophobins, which occur uniquely in mycelial fungi and have been identified in fungi from the phyla Basidiomycota and Ascomycota (Linder et al., 2005; Linder, 2009; Wessels, 1997; Whiteford and Spanu, 2002; Wösten, 2001). These hydrophobic rodlet layers are generally found on the outer surfaces of spores and cause them to have a hydrophobic interface. Since it is thought that a major requirement for adequate IN ability is a surface that can undergo hydrogen bonding (Pruppacher and Klett, 1997), it is not surprising that the studied Cladosporium spores appear to be poor IN.

\subsection{Atmospheric implications}

Above $-15^{\circ} \mathrm{C}$, many mineral dusts become ineffective IN, although some field experiments show that some mineral dust particles are effective ice nuclei as warm as -5.2 to $-8.8^{\circ} \mathrm{C}$ (Sassen et al., 2003). It has been suggested that the most important carbonaceous particles acting as ice nuclei above $-15^{\circ} \mathrm{C}$ may be biological particles (DeMott and Prenni, 2010). Our data suggests that, at temperatures above $-15^{\circ} \mathrm{C}$, Cladosporium spores are not likely an important IN species in the atmosphere. Over this temperature range, we can expect that less than $0.5 \%$ will nucleate ice as a very conservative estimate from our data. Assuming that concentrations of fungal spores are on the order of $\sim 10 \mathrm{~L}^{-1}$ in the atmosphere (Elbert et al., 2007), based on measurements in the boundary layer, and as an upper limit we assume that $50 \%$ of all spores are from the genus Cladosporium, it is estimated 


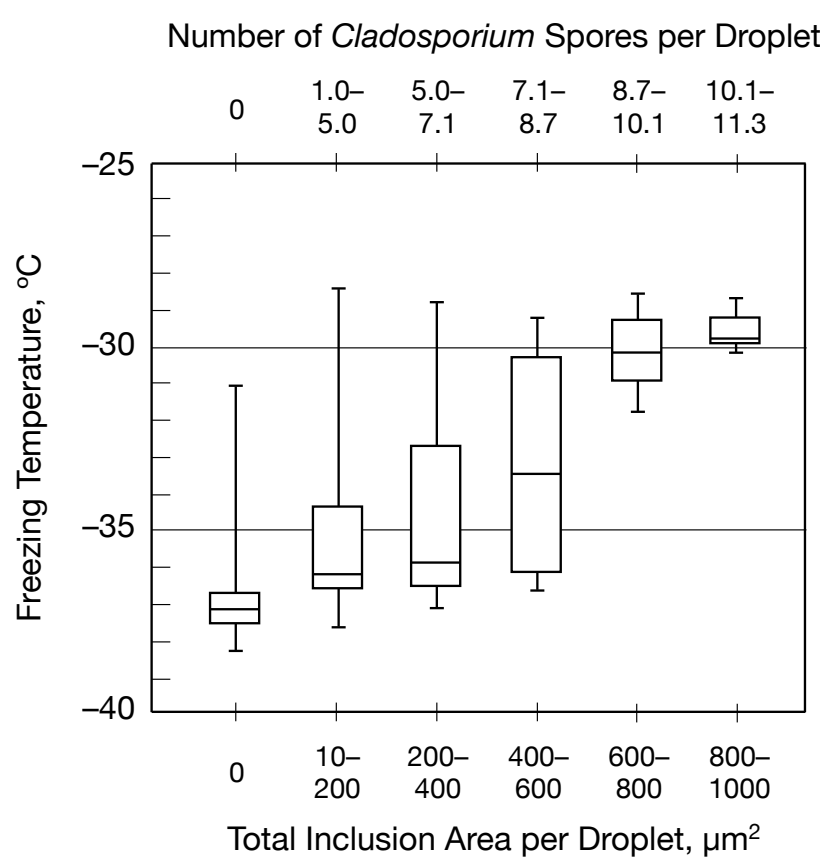

Fig. 8. Box plot showing a five-number statistical summary for homogeneous nucleation experiments (leftmost box) and binned data from all heterogeneous nucleation experiments. Each box represents temperatures as maximum and minimum values, and the $1 \mathrm{st}$, 2nd (median), and 3rd quartiles. Freezing data are distributed into $200 \mu \mathrm{m}^{2}$ bins that represent the total area of all observable inclusions per frozen droplet (bottom x-axis). The average uncertainty in the inclusion area is $\pm 28 \mu \mathrm{m}^{2}$. Assuming that all inclusions are spores with a mean volume equivalent diameter of $3.2 \mu \mathrm{m}$, the top $\mathrm{x}$-axis provides the numbers of Cladosporium spores corresponding to each area bin.

that the number of IN from Cladosporium spores is significantly less than $\sim 0.025 \mathrm{~L}^{-1}$. This value is a factor of approximately 4 to 800 smaller than the number of IN observed in the atmosphere at temperatures around $-15^{\circ} \mathrm{C}$ (DeMott et al., 2010).

At low temperatures (i.e., $-25^{\circ} \mathrm{C}$ to $-35^{\circ} \mathrm{C}$ ) spores of Cladosporium and other similar spores may compete with other active IN (e.g., mineral dust). Modelling studies are required to assess the importance of Cladosporium in this temperature range. As mentioned above, Cladosporium has a similar ice nucleation ability in the immersion mode to kaolinite, which is an abundant mineral dust in the atmosphere (Murray et al., 2010; Lüönd et al., 2010).

A recent study concerning biological IN in the wet season over the Amazon rainforest has demonstrated that the level of atmospheric IN can be predicted through measurements of a combination of mineral dust and biological particles (Prenni et al., 2009). To explain their data, Prenni et al. had assumed that the sampled biological particles could induce ice nucleation with an efficiency of $\sim 0.2$ for temperatures between -18 and $-31^{\circ} \mathrm{C}$. At temperatures above approx- imately $-25^{\circ} \mathrm{C}$, biological particles appeared to dominate. The size range of IN measured by Prenni et al. (2009) was $\leq 1.3 \mu \mathrm{m}$ in aerodynamic diameter. Some species of fungi can produce spores in this size range, but the fraction of $\mathrm{Cla}$ dosporium spores in this size range is very small. In addition, for Cladosporium, less than $0.5 \%$ of the droplets were observed to freeze at temperatures above $-25^{\circ} \mathrm{C}$ according to Fig. 6. Hence, Cladosporium spores cannot explain the observations by Prenni et al. (2009) Some other type of biological material must have been active as ice nuclei in these studies.

In a recent study by Pratt et al. (2009), ice residuals collected in situ from cloud particles at $-31^{\circ} \mathrm{C}$ to $-34{ }^{\circ} \mathrm{C}$ contained a significant fraction of biological material. There was, however, a notable size cutoff: ice residual particles $>700 \mathrm{~nm}$ were not admitted to their MS instrument (for identification of biological markers within individual particles; a total of 46 particles were examined). The number of intact spores with aerodynamic diameters less than $700 \mathrm{~nm}$ in the atmosphere is likely very small (Fröhlich-Nowoisky et al., 2009; Hameed and Khodr, 2001; Jung et al., 2009a; Reponen et al., 2001). Hence, some other biological material, besides intact fungal spores, was likely responsible for the observations by Pratt et al. (2009).

\section{Summary and conclusions}

Given the lack of published studies on the heterogeneous freezing of fungal spores, cloud modelling calculations incorporating the effect of fungal spores have relied on assumptions. We focused on one of the most abundant types of fungal spores found in the atmosphere: spores from the genus Cladosporium. The onsets for heterogeneous freezing of pure water droplets containing spores of Cladosporium occurred as high as $-28.4^{\circ} \mathrm{C}$. However, there was a strong dependence between the freezing temperature and the total spore surface area of Cladosporium for a given droplet. As such, mean freezing temperatures for droplets containing 15 spores are expected to be approximately $-35.1 \pm 2.3^{\circ} \mathrm{C}$. Our result suggests that fungal spores are ineffective IN at temperatures warmer than $-15^{\circ} \mathrm{C}$. Assuming that the concentration of all types of fungal spores in the atmosphere is $\sim 10 \mathrm{~L}^{-1}$ and that $50 \%$ of these spores are of Cladosporium, the number of IN from Cladosporium spores is estimated as $\sim 0.025 \mathrm{~L}^{-1}$. The poor ice nucleation ability of Cladosporium spores compared to the bacterial IN $P$. syringae can be rationalized on the basis of the spore surface of Cladosporium, which is coated with hydrophobins (a class of hydrophobic proteins that appear to be widespread in filamentous fungi). By comparison, the surface of $P$. syringae is believed to contain a protein that provides a hydrogen-bonding lattice match to ice.

Spores of Cladosporium may, nevertheless, compete with other active IN such as mineral dust at temperatures from 
$-25^{\circ} \mathrm{C}$ to $-35^{\circ} \mathrm{C}$. A detailed modelling study is required to examine their impacts over this temperature range. The conclusions in this paper are based on fungal spores obtained from one species of fungi. For further generalization, studies on other types of fungal spores are required. However, it is interesting to note that hydrophobins are thought to be ubiquitous in filamentous fungi, rendering the bulk of species as unlikely candidates for effective IN based on our current understanding of heterogeneous ice nucleation.

Acknowledgements. This research was supported financially by the Natural Sciences and Engineering Research Council of Canada (NSERC) and the Canada Research Chairs Program. The authors thank E. Polishchuk and J. Chen of the Biological Services Laboratory (UBC Department of Chemistry) for their invaluable assistance.

\section{Edited by: R. Krejci}

\section{References}

Abbatt, J. P. D., Benz, S., Cziczo, D. J., Kanji, Z. A., Lohmann, U., and Möhler, O.: Solid ammonium sulfate aerosols as ice nuclei: a pathway for cirrus cloud formation, Science, 313, 1770-1773, 2006.

Aimanianda, V., Bayry, J., Bozza, S., Kniemeyer, O., Perruccio, K., Elluru, S. R., Clavaud, C., Paris, S., Brakhage, A. A., Kaveri, S. V., Romani, L., and Latgé, J.-P.: Surface hydrophobin prevents immune recognition of airborne fungal spores, Nature, 460, 1117-1121, 2009.

Al-Subai, A. A. T.: Air-borne fungi at Doha, Qatar, Aerobiologia, 18, 175-183, 2002.

Andreae, M. O. and Rosenfeld, D.: Aerosol-cloud-precipitation interactions, Part 1. The nature and sources of cloud-active aerosols, Earth-Sci. Rev., 89, 13-41, 2008.

Archuleta, C. M., DeMott, P. J., and Kreidenweis, S. M.: Ice nucleation by surrogates for atmospheric mineral dust and mineral dust/sulfate particles at cirrus temperatures, Atmos. Chem. Phys., 5, 2617-2634, doi:10.5194/acp-5-2617-2005, 2005.

Ariya, P. A., Sun, J., Eltouny, N., Hudson, E., Hayes, C. T., and Kos, G.: Physical and chemical characterization of bioaerosols implications for nucleation processes, Int. Rev. Phys. Chem., 28, 1-32, doi:10.1080/01442350802597438, 2009.

Ashworth, E. N. and Kieft, T. L.: Measurement of ice nucleation in lichens using thermal analysis, Cryobiology, 29, 400-406, 1992.

Baker, M. B. and Peter, T.: Small-scale cloud processes and climate, Nature, 451, 299-300, 2008.

Bertram, A. K., Koop, T., Molina, L. T., and Molina, M. J.: Ice formation in $\left(\mathrm{NH}_{4}\right)_{2} \mathrm{SO}_{4}-\mathrm{H}_{2} \mathrm{O}$ particles, J. Phys. Chem. A, 104, 584-588, doi:10.1021/jp9931197, 2000.

Carlile, M. J., Watkinson, S. C., and Gooday, G. W.: The Fungi, 2nd ed., Academic Press, London, UK, 608 pp., 2001.

Christner, B. C., Morris, C. E., Foreman, C. M., Cai, R., and Sands, D. C.: Ubiquity of biological ice nucleators in snowfall, Science, 319, 1214-1214, doi:10.1126/science.1149757, 2008.

Davies, R. R.: A study of air-borne Cladosporium, T. Brit. Mycol. Soc., 40, 409-414, 1957.

DeMott, P. J., Cziczo, D. J., Prenni, A. J., Murphy, D. M., Kreidenweis, S. M., Thomson, D. S., Borys, R., and Rogers, D. C.:
Measurements of the concentration and composition of nuclei for cirrus formation, P. Natl. Acad. Sci. USA, 100, 14655-14660, doi:10.1073/pnas.2532677100, 2003.

DeMott, P. J. and Prenni, A. J.: New directions: need for defining the numbers and sources of biological aerosols acting as ice nuclei, Atmos. Environ., 44, 1944-1945, 2010.

DeMott, P. J., Prenni, A. J., Liu, X., Kreidenweis, S. M., Petters, M. D., Twohy, C. H., Richardson, M. S., Eidhammer, T., and Rogers, D. C.: Predicting global atmospheric ice nuclei distributions and their impacts on climate, P. Natl. Acad. Sci. USA, 107, 1121711222, 2010.

Diehl, K., Quick, C., Matthias-Maser, S., Mitra, S., and Jaenicke, R.: The ice nucleating ability of pollen - Part I: Laboratory studies in deposition and condensation freezing modes, Atmos. Res., 58, 75-87, doi:10.1016/S0169-8095(01)00091-6, 2001.

Diehl, K., Matthias-Maser, S., Jaenicke, R., and Mitra, S.: The ice nucleating ability of pollen - Part II: Laboratory studies in immersion and contact freezing modes, Atmos. Res., 61, 125133, doi:10.1016/S0169-8095(01)00132-6, 2002.

Diehl, K., Simmel, M., and Wurzler, S.: Numerical sensitivity studies on the impact of aerosol properties and drop freezing modes on the glaciation, microphysics, and dynamics of clouds, J. Geophys. Res., 111, D07202, doi:10.1029/2005JD005884, 2006.

Dymarska, M., Murray, B. J., Sun, L., Eastwood, M. L., Knopf, D. A., and Bertram, A. K.: Deposition ice nucleation on soot at temperatures relevant for the lower troposphere, J. Geophys. Res., 111, D04204, doi:10.1029/2005JD006627, 2006.

Eastwood, M. L., Cremel, S., Gehrke, C., Girard, E., and Bertram, A. K.: Ice nucleation on mineral dust particles: onset conditions, nucleation rates and contact angles, J. Geophys. Res., 113, D22203, doi:10.1029/2008JD010639, 2008.

Elbert, W., Taylor, P. E., Andreae, M. O., and Pöschl, U.: Contribution of fungi to primary biogenic aerosols in the atmosphere: wet and dry discharged spores, carbohydrates, and inorganic ions, Atmos. Chem. Phys., 7, 4569-4588, doi:10.5194/acp-7-4569-2007, 2007.

Fröhlich-Nowoisky, J., Pickersgill, D. A., Després, V. R., and Pöschl, U.: High diversity of fungi in air particulate matter, P. Natl. Acad. Sci. USA, 106, 12814-12819, doi:10.1073/pnas.0811003106, 2009.

Fulton, J. D.: Microorganisms of the upper atmosphere. III. Relationship between altitude and micropopulation, Appl. Microbiol., 14, 237-240, 1996.

Fulton, J. D. and Mitchell, R. B.: Microorganisms of the upper atmosphere. II. Microorganisms in two types of air masses at 690 meters over a city, Appl. Microbiol., 14, 232-236, 1966.

Gilbert, G. S. and Reynolds, D. R.: Nocturnal fungi: Airborne spores in the canopy and understory of a tropical rain forest, Biotropica, 37, 462-464, 2005.

Green, R. L. and Warren, G. J.: Physical and functional repetition in a bacterial ice nucleation gene, Nature, 317, 645-648, 1985.

Gregory, P. H.: Distribution of airborne pollen and spores and their long distance transport, Pure Appl. Geophys., 116, 309-315, 1978.

Gurian-Sherman, D. and Lindow, S. E.: Bacterial ice nucleation: Significance and molecular basis, FASEB J., 7, 1338-1343, 1993.

Hameed, A. A. A., and Khodr, M. I.: Suspended particulates and bioaerosols emitted from an agricultural non-point source, J. En- 
viron. Monit., 3, 206-209, 2001.

Harvey, R.; Air-spora studies at Cardiff: I. Cladosporium, Trans. Brit. Mycol. Soc., 50, 479-495, 1967.

Hegg, D. A. and Baker, M. B.: Nucleation in the atmosphere, Rep. Prog. Phys., 72, 056801, doi:10.1088/0034-4885/72/5/056801, 2009.

Heise, H. A. and Heise, E. R.: The distribution of ragweed pollen and alternaria spores in the upper atmosphere, J. Allergy, 19, 403-407, 1948.

Herrero, A. D., Ruiz, S. S., Bustillo, M. G., and Morales, P. C.: Study of airborne fungal spores in Madrid, Spain, Aerobiologia, 22, 135-142, 2006.

Hirst, J. M.: Changes in atmospheric spore content: diurnal periodicity and the effects of weather, Trans. Brit. Mycol. Soc., 36, 375-393, 1953.

Hirst, J. M., Stedman, O. J., and Hogg, W. H.: Long-distance spore transport: methods of measurement, vertical spore profiles and the detection of immigrant spores, J. Gen. Microbiol., 48, 329355, 1967a.

Hirst, J. M., Stedman, O. J., and Hurst, G. W.: Long-distance spore transport: vertical sections of spore clouds over the sea, J. Gen. Microbiol., 48, 357-377, 1967b.

Hoose, C., Kristjánsson, J. E., and Burrows, S. M.: How important is biological ice nucleation in clouds on a global scale?, Environ. Res. Lett., 5, 024009, doi:10.1088/1748-9326/5/2/024009, 2010.

Hung, H.-M., Malinowski, A., and Martin, S. T.: Kinetics of heterogeneous ice nucleation on the surfaces of mineral dust cores inserted into aqueous ammonium sulfate particles, J. Phys. Chem. A, 107, 1296-1306, 2003.

Hyde, H. A. and Williams, D. A.: The incidence of Cladosporium herbarum in the outdoor air at Cardiff, 1949-1950, T. Brit. Mycol. Soc., 36, 260-266, 1953.

Imshenetsky, A. A., Lysenko, S. V., and Kazakov, G. A.: Upper boundary of the biosphere, Appl. Environ. Microb., 35, 1-5, 1978.

Jung, J. H., Lee, C. H., Lee, J. E., Lee, J. H., Kim, S. S., and Lee, B. U.: Design and characterization of a fungal bioaerosol generator using multi-orifice air jets and a rotating substrate, J. Aerosol Sci., 40, 72-80, doi:10.1016/j.jaerosci.2008.09.002, 2009a.

Jung, J. H., Lee, J. E., Lee, C. H., Kim, S. S., and Lee, B. U.: Treatment of fungal bioaerosols by a high-temperature, shorttime process in a continuous-flow system, Appl. Environ. Microb., 75, 2742-2749, doi:10.1128/AEM.01790-08, 2009b.

Kajava, A. V. and Lindow, S. E.: A model of the three-dimensional structure of ice nucleation proteins, J. Mol. Biol., 232, 709-717, 1993.

Kanji, Z. A., Florea, O., and Abbatt, J. P. D.: Ice formation via deposition nucleation on mineral dust and organics: dependence of onset relative humidity on total particulate surface area, Environ. Res. Lett., 3, 025004, doi:10.1088/1748-9326/3/2/025004, 2008.

Kärcher, B., Möhler, O., DeMott, P. J., Pechtl, S., and Yu, F.: Insights into the role of soot aerosols in cirrus cloud formation, Atmos. Chem. Phys., 7, 4203-4227, doi:10.5194/acp-7-4203-2007, 2007.

Kelly, C. D. and Pady, S. M.: Microbiological studies of air over some nonarctic regions of Canada, Can. J. Botany, 31, 90-106, 1953.

Kieft, T. L.: Ice nucleation activity in lichens, Appl. Environ. Microb., 54, 1678-1681, 1988.
Kieft, T. L. and Ahmadjian, V.: Biological ice nucleation activity in lichen mycobionts and photobionts, Lichenologist, 21, 355-362, 1989.

Kieft, T. L. and Ruscetti, T.: Characterization of biological ice nuclei from a lichen, J. Bacteriol., 172, 3519-3523, 1990.

Koop, T., Ng, H., Molina, L. T., and Molina, M. J.: A new optical technique to study aerosol phase transitions: The nucleation of ice from $\mathrm{H}_{2} \mathrm{SO}_{4}$ aerosols, J. Phys. Chem. A, 102, 8924-8931, 1998.

Kurkela, T.: The number of Cladosporium conidia in the air in different weather conditions, Grana, 36, 54-61, 1997.

Latgé, J.-P., Bouziane, H., and Diaquin, M.: Ultrastructure and composition of the conidial wall of Cladosporium cladosporioides, Can. J. Microbiol., 34, 1325-1329, 1988.

Lee, R. E., Warren, G. J., and Gusta, L. V. (eds.): Biological ice nucleation and its applications, American Phytopathological Society, St. Paul, MN, ISBN 978-0-89054-172-2, 370 pp., 1995.

Li, D.-W. and Kendrick, B.: A year-round outdoor aeromycological study in Waterloo, Ontario, Canada, Grana, 34, 199-207, 1995.

Lim, S. H., Chew, F. T., Dali, S. D. B. M., Tan, H. T. W., Lee, B. W., and Tan, T. K.: Outdoor airborne fungal spores in Singapore, Grana, 37, 246-252, 1998.

Linder, M. B.: Hydrophobins: proteins that self assemble at interfaces, Curr. Opin. Colloid In., 14, 356-363, doi:10.1016/j.cocis.2009.04.001, 2009.

Linder, M. B., Szilvay, G. R., Nakari-Setälä, T., and Penttilä, M. E.: Hydrophobins: the protein-amphiphiles of filamentous fungi, FEMS Microbiol. Rev., 29, 877-896, 2005.

Lindow, S. E., Lahue, E., Govindarajan, A. G., Panopoulos, N. J., and Gies, D.: Localization of ice nucleation activity and the iceC gene product in Pseudomonas syringae and Escherichia coli, Mol. Plant Microbe In., 2, 262-272, 1989.

Lohmann, U. and Hoose, C.: Sensitivity studies of different aerosol indirect effects in mixed-phase clouds, Atmos. Chem. Phys., 9, 8917-8934, doi:10.5194/acp-9-8917-2009, 2009.

Lüönd, F., Stetzer, O., Welti, A., and Lohmann, U.: Experimental study on the ice nucleation ability of size-selected kaolinite particles in the immersion mode, J. Geophys. Res., 115, D14201, doi:10.1029/2009JD01295, 2010.

Maki, L. R., Galyan, E. L., Chang-Chien, M.-M., and Caldwell, D. R.: Ice nucleation induced by Pseudomonas syringae, Appl. Microbiol., 28, 456-459, 1974.

Mallo, A., Nitiu, D., and Gardella Sambeth, M.: Airborne fungal spore content in the atmosphere of the city of La Plata, Argentina, Aerobiologia, 27(1), 77-84 doi:10.1007/s10453-1001019172-10450, 2011.

Marcolli, C., Gedamke, S., Peter, T., and Zobrist, B.: Efficiency of immersion mode ice nucleation on surrogates of mineral dust, Atmos. Chem. Phys., 7, 5081-5091, doi:10.5194/acp-7-50812007, 2007.

Martin, S. T.: Phase transformations of the ternary system $\left(\mathrm{NH}_{4}\right)_{2} \mathrm{SO}_{4}-\mathrm{H}_{2} \mathrm{SO}_{4}-\mathrm{H}_{2} \mathrm{O}$ and the implications for cirrus cloud formation, Geophys. Res. Lett., 25, 1657-1660, 1998.

Martin, S. T., Andreae, M. O., Artaxo, P., Baumgardner, D., Chen, Q., Goldstein, A. H., Guenther, A., Heald, C. L., Mayol-Bracero, O. L., McMurry, P. H., Pauliquevis, T., Pöschl, U., Prather, K. A., Roberts, G. C., Saleska, S. R., Silva Dias, M. A., Spracklen, D. V., Swietlicki, E., and Trebs, I.: Sources and properties of Amazonian aerosol particles, Rev. Geophys., 48, RG2002, 
doi:10.1029/2008RG000280, 2010.

Mitakakis, T. Z. and Guest, D. I.: A fungal spore calendar for the atmosphere of Melbourne, Australia, for the year 1993, Aerobiologia, 17, 171-176, 2001.

Möhler, O., DeMott, P. J., Vali, G., and Levin, Z.: Microbiology and atmospheric processes: the role of biological particles in cloud physics, Biogeosciences, 4, 1059-1071, doi:10.5194/bg-4-10592007, 2007.

Morris, C. E., Georgakopoulos, D., and Sands, D.: Ice nucleation active bacteria and their potential role in precipitation, J. Phys IV, 121, 87-103, doi:10.1051/jp4:2004121004, 2004.

Murray, B. J., Wilson, T. W., Broadley, S. L., and Wills, R. H.: Heterogeneous freezing of water droplets containing kaolinite and montmorillonite particles, Atmos. Chem. Phys. Discuss., 10, 9695-9729, 2010,

http://www.atmos-chem-phys-discuss.net/10/9695/2010/.

Nash III, T. H.: Lichen Biology, 2nd ed., Cambridge University Press, New York, 496 pp., 2008.

Pady, S. M. and Kelly, C. D.: Numbers of fungi and bacteria in transatlantic air, Science, 117, 607-609, 1953.

Parsons, M. T., Mak, J., Lipetz, S. R., and Bertram, A. K.: Deliquescence of malonic, succinic, glutaric, and adipic acid particles, J. Geophys. Res., 109, D06212, doi:10.1029/2003JD004075, 2004.

Phillips, V. T. J., DeMott, P. J., and Andronache, C.: An empirical parameterization of heterogeneous ice nucleation for multiple chemical species of aerosol, J. Atmos. Sci., 65, 2757-2783, 2008.

Phillips, V. T. J., Andronache, C., Christner, B., Morris, C. E., Sands, D. C., Bansemer, A., Lauer, A., McNaughton, C., and Seman, C.: Potential impacts from biological aerosols on ensembles of continental clouds simulated numerically, Biogeosciences, 6, 987-1014, doi:10.5194/bg-6-987-2009, 2009.

Pouleur, S., Richard, C., Martin, J.-G., and Antouin, H.: Ice nucleation activity in Fusarium acuminatum and Fusarium avenaceum, Appl. Environ. Microb., 58, 2960-2964, 1992.

Pratt, K. A., DeMott, P. J., French, J. R., Wang, Z., Westphal, D. L., Heymsfield, A. J., Twohy, C. H., Prenni, A. J., and Prather, K. A.: In situ detection of biological particles in cloud ice-crystals, Nat. Geosci., 2, 397-400, doi:10.1038/NGEO521, 2009.

Prenni, A. J., Petters, M. D., Kreidenweis, S. M., Heald, C. L., Martin, S. T., Artaxo, P., Garland, R. M., Wollny, A. G., and Pöschl, U.: Relative roles of biogenic emissions and Saharan dust as ice nuclei in the Amazon basin, Nat. Geosci., 2, 401-404, doi:10.1038/NGEO517, 2009.

Proctor, B. E.: The microbiology of the upper air. II, J. Bacteriol., 30, 363-375, 1935.

Proctor, B. E. and Parker, B. W.: Microbiology of the upper air. III. An Improved apparatus and technique for upper air investigations, J. Bacteriol., 36, 175-185, 1938.

Pruppacher, H. R.: A new look at homogeneous ice nucleation in supercooled water drops, J. Atmos. Sci., 52, 1924-1933, 1995.

Pruppacher, H. R. and Klett, J. D.: Microphysics of Clouds and Precipitation, Kluwer Academic Publishers, Dordrecht, 954 pp., 1997.

Pyrri, I. and Kapsanaki-Gotsi, E.: A comparative study on the airborne fungi in Athens, Greece, by viable and non-viable sampling methods, Aerobiologia, 23, 3-15, 2007.

Reponen, T., Willeke, K., Ulevicius, V., Grinshpun, S. A., and Donnelly, J.: Techniques for dispersion of microorganisms into air,
Aerosol Sci. Tech., 27, 405-421, 1997.

Reponen, T., Grinshpun, S. A., Conwell, K. L., Wiest, J., and Anderson, M.: Aerodynamic versus physical size of spores: measurement and implication for respiratory deposition, Grana, 40 119-125, 2001.

Sands, D. C., Langhans, V. E., Scharen, A. L., and de Smet, G.: The association between bacteria and rain and possible resultant meteorological implications, J. Hungarian Meteorol. Serv., 86, 148-152, 1982.

Sassen, K., DeMott, P. J., Prospero, J. M., and Poellot, M. R.: Saharan dust storms and indirect aerosol effects on clouds: CRYSTAL-FACE results, Geophys. Res. Lett., 30, 1633, doi:10.1029/2003GL017371, 2003.

Schubert, K., Groenewald, J. Z., Braun, U., Dijksterhuis, J., Starink, M., Hill, C. F., Zalar, P., de Hoog, G. S., and Crous, P. W.: Biodiversity in the Cladosporium herbarium complex (Davidiellaceae, Capnodiales), with standardisation of methods for Cladosporium taxonomy and diagnostics, Stud. Mycol., 58, 105-156, 2007.

Shilling, J. E., Fortin, T. J., and Tolbert, M. A.: Depositional ice nucleation on crystalline organic and inorganic solids, J. Geophys. Res., 111, D12204, doi:10.1029/2005JD006664, 2006.

Stennett, P. J. and Beggs, P. J.: Alternaria spores in the atmosphere of Sydney, Australia, andrelationships with meteorological factors, Int. J. Biometeorol., 49, 98-105, 2004.

Stępalska, D., and Wołek, J.: Intradiurnal periodicity of fungal spore concentrations (Alternaria, Botrytis, Cladosporium, Didymella, Ganoderma) in Cracow, Poland, Aerobiologia, 25, 333-340, 2009.

Szyrmer, W. and Zawadzki, I.: Biogenic and anthropogenic sources of ice-forming nuclei: a review, B. Am. Meteorol. Soc., 78, 209 228, 1997.

Vali, G., Christensen, M., Fresh, R. W., Galyan, E. L., Maki, L. R., and Schnell, R. C.: Biogenic ice nuclei. Part II: Bacterial sources, J. Atmos. Sci., 33, 1565-1570, 1976.

von Blohn, N., Mitra, S., Diehl, K., and Borrmann, S.: The ice nucleating ability of pollen. Part III: New laboratory studies in immersion and contact freezing modes including more pollen types, Atmos. Res., 78, 182-189, doi:10.1016/j.atmosres.2005.03.008, 2005.

Wessels, J. G. H.: Hydrophobins: proteins that change the nature of the fungal surface, Adv. Microb. Physiol., 38, 1-45, 1997.

Whiteford, J. R. and Spanu, P. D.: Hydrophobins and the interactions between fungi and plants, Mol. Plant Pathol., 3, 391-400, 2002.

Wise, M. E., Baustian, K. J., and Tolbert, M. A.: Internally mixed sulfate and organic particles as potential ice nuclei in the tropical tropopause region, P. Natl. Acad. Sci. USA, 107, 6693-6698, 2010.

Wood, S., Baker, M., and Swanson, B.: Instrument for studies of homogeneous and heterogeneous ice nucleation in free-falling supercooled water droplets, Rev. Sci. Instrum., 73, 3988-3996, doi:10.1063/1.1511796, 2002.

Wösten, H. A. B.: Hydrophobins: Multipurpose proteins, Ann. Rev. Microbiol., 55, 625-646, 2001.

Zuberi, B., Bertram, A. K., Cassa, C. A., Molina, L. T., and Molina, M. J.: Heterogeneous nucleation of ice in $\left(\mathrm{NH}_{4}\right)_{2} \mathrm{SO}_{4}-\mathrm{H}_{2} \mathrm{O}$ particles with mineral dust immersions, Geophys. Res. Lett., 29, 1504, doi:10.1029/2001GL014289, 2002. 